\title{
THE 1918 CÓRDOBA REFORM AND UNIVERSITY INTERNATIONALIZATION IN LATIN AMERICA
}

\author{
Maria Julieta Abba* \\ Danilo Romeu Streck ${ }^{* *}$
}

\begin{abstract}
Internationalization is a trend that, in the last two decades, has been firmly established in Latin America. However, this article argues that it is part of a historical process that has been constituted within the region with characteristics of its own. For this reason, this paper aims to identify the contributions of the 1918 Cordoba Reform to the analysis of the university internationalization process in Latin America. A bibliographical and documentary research with a historical content was carried out. Its result points out that the legacy of the reform, with regard to regional integration and the concept of university autonomy, contributes to a view of internationalization rooted in the Latin American context.
\end{abstract}

Keywords: Latin America, history of education, Córdoba Reform, internationalization, university.

* Universidade do Vale do Rio dos Sinos (UNISINOS), São Leopoldo/RS, Brasil.

**Universidade de Caxias do Sul (UCS), Caxias do Sul/RS, Brasil. 


\section{REFORMA DE CÓRDOBA DE 1918 E A INTERNACIONALIZAÇÃO UNIVERSITÁRIA NA AMÉRICA LATINA}

\section{RESUMO}

A internacionalização é uma tendência que, nas últimas duas décadas, tem-se instalado com força no âmbito universitário latino-americano. Contudo, argumenta-se neste artigo que ela é parte de um processo histórico que vem se constituindo dentro da região com características lhe são próprias. Por isso, este trabalho tem como objetivo identificar as contribuições da Reforma de Córdoba de 1918 para a análise do processo de internacionalização universitária na América Latina. Realizou-se uma pesquisa bibliográfica e documental, com um conteúdo de cunho histórico. Aponta-se como resultado que o legado da reforma, no que se refere à integração regional e ao conceito de autonomia universitária, contribui para uma visão da internacionalização enraizada no contexto latino-americano.

Palavras-chave: América Latina, história da educação, Reforma de Córdoba, internacionalização, universidade.

\section{LA REFORMA DE CORDOBA DE 1918 Y LA INTERNACIONALIZACIÓN UNIVERSITARIA EN AMÉRICA LATINA}

\section{RESUMEN}

La internacionalización es una tendencia que, en las últimas dos décadas, se ha instalado con fuerza en el ámbito universitario latinoamericano. Sin embargo, en este artículo se argumenta que ella forma parte de un proceso histórico que se viene constituyendo dentro de la región con características propias. Por eso, este trabajo tiene como objetivo identificar las contribuciones de la Reforma de Córdoba de 1918 para el análisis del proceso de internacionalización universitaria en América Latina. Se realizó una investigación bibliográfica y documental, con un contenido de cuño histórico. Se apunta como resultado que el legado de la reforma, en lo que se refiere a la integración regional y al concepto de autonomía universitaria, contribuye para una visión de internacionalización enraizada en el contexto latinoamericano.

Palabras clave: América Latina, historia de la educación, Reforma de Córdoba, internacionalización, universidad.

\section{LA RÉFORME DE CORDOBA DE 1918 ET L'INTERNATIONALISATION DE L'UNIVERSITÉ EN AMÉRIQUE LATINE}

\section{RESUME}

L'internationalisation est une tendance qui, au cours des deux dernières décennies, s'est fortement implantée dans l'environnement universitaire latino-américain. Cependant, dans cet 
article, il est soutenu qu'il fait partie d'un processus historique qui s'est déroulé dans la région avec ses propres caractéristiques. Par conséquent, ce travail vise à identifier les contributions de la réforme de Cordoue de 1918 pour l'analyse du processus d'internationalisation universitaire en Amérique latine. Une enquête bibliographique et documentaire a été menée, avec un contenu historique. Il en résulte que l'héritage de la réforme, concernant l'intégration régionale et le concept d'autonomie universitaire, contribue à une vision de l'internationalisation ancrée dans le contexte latino-américain.

Mots-clés: Amérique latine, histoire de l'éducation, Réforme de Cordoue, internationalisation, université. 


\section{INITIAL CONSIDERATIONS ${ }^{1}$}

Los dolores que quedan son las libertades que faltan. Creemos no equivocarnos, las resonancias del corazón nos lo advierten: estamos pisando sobre una revolución, estamos viviendo una hora americana (BARROS, et al. [1918] 2017, p. 27).

The 1918 University Reform, which took place in the city of Córdoba, Argentina, was one of the most important episodes of the $20^{\text {th }}$ century with regard to higher education in Latin America. It founded a student movement engaged with the problems that affected the university at that time, linked mainly to the elitist, scholastic and ecclesiastical nature of teaching, assuming that these issues were common to Latin American universities. From Córdoba, a seed was sown, whose fruits were also reaped in other countries, where there was favorable ground for the organization of a student movement willing to transform the conservative standards that surrounded the university and society too. The protagonists of this process began to circulate in several Latin American countries to disseminate their ideas, to exchange proposals, as well as to search for support and establish partnerships. In this way, the meaning of the Reform spread across the continent, impacting the organization of the student movement, the structures of university systems and society in general.

Due to this internationalist character, we consider that the 1918 Córdoba Reform is constitutive of the historical process of university internationalization in Latin America. In this sense, although the higher education internationalization concept emerged as of the 1990s (ALTBACH, 1989; DE WIT, 1995; KNIGHT, 1994; TEICHLER, 1999), our argument is that internationalization is a historical process that was present in the universities since their creation (GARCIA GUADILLA, 2005; TÜNERMANN BERNHEIM, 1996). For instance, from the $12^{\text {th }}$ century onwards, European institutions such as Bologna, Salamanca, Oxford, Cambridge and Coimbra constituted themselves

\footnotetext{
${ }^{1}$ English version translated by Maria Dolores Dalpasquale. Email: dolorestradutora@gmail.com
} 
around the exchange and gathering of professors and students from different regions. In Latin America, for its part, this exchange was generated through the trips that the children of the local elites took to the colonial centers to educate themselves and better learn different languages. Likewise, the birth of Latin American universities also had an international sense, as they were created as Spanish universities in America under the religious domain of the Jesuit order.

However, this internationalization has evolved throughout the history of education in several ways, until it reaches the present time, when, thanks to the phenomenon of globalization (ALTBACH; KNIGHT, 2006; DE WIT, 2011), it has become a topic of central importance for universities, for public policies on higher education (DE WIT, 2020) and a priority for some international organizations such as UNESCO (United Nations Educational, Scientific and Cultural Organization) and the OECD (Organization for Economic Co-operation and Development). Thus, internationalization in the context of globalization intensified the international connections (both physical and virtual) of the main actors of education, strengthening communication, interaction, and exchanges between the main actors in the education field. It is important to stress that this view of globalization as a set of [...] economic, political, and social forces driving $21^{\text {st }}$ century higher education towards greater international involvement (ALTBACH, KNIGHT, 2006, p. 14) has been the subject of several questions. One of them, supported by Stein (2017), brings arguments that question globalization as an inevitable and benign process, and internationalization as a mere reaction to said process. In this sense, globalization and internationalization, understood as neutral, can be used to justify geopolitical relations in the neoliberal context (STEIN, 2017) and to deny the relations that support the coloniality of power (QUIJANO, 2014). For this reason, in this article we understand university internationalization as:

[...] the intentional process of integrating an international, intercultural or global dimension into the purpose, functions and delivery of postsecondary education, in order to enhance the quality of education and 
research for all students and staff, and to make a meaningful contribution to society (DE WIT et al., 2015, p. 29, emphasis added).

Linked to this definition, the internationalization process currently faces great challenges in a political climate of growing nationalism, racism and xenophobia (ALTBACH; DE WIT, 2017). The increase in the various forms of commercialization of higher education has also had an impact on the internationalization and quality of education, generating a proliferation of corporate universities and virtual universities belonging to international-capital groups (ABBA, 2018). Another challenge that is presented is the proliferation of different ways of implementing internationalization in universities. Concepts such as Internationalization at Home or Collaborative Online International Learning began to stand out in the internationalization field, focusing on the virtual modality. However, the international physical mobility of students and professors remains a growing trend, though limited and uneven, in regional terms (DIDOU AUPETIT, 2017), between universities in the North and South. ${ }^{2}$

In this context, we start from the assumption that it is important to revisit moments in the history of Latin American universities and ask ourselves the following questions: What events set a precedent for internationalization in the university system in Latin America? What are the contributions of these facts to reflections on current practices and policies? And finally, how can a historical view of education contribute to us thinking of an inclusive and democratic internationalization for all social sectors? In view of said questions, in the present article we aim to identify the contributions of the 1918 Córdoba Reform to the analysis of the current university internationalization process in Latin America.

As for its methodology, this research is characterized as a qualitative one, of the historical-structural type, as it focuses on describing not only "[...] the

\footnotetext{
${ }^{2}$ In this article, we refer to the North and the South not only as geographical areas, but also as analytical categories that represent a hierarchy and marginalization imposed by the colonial capitalist power (SOUSA SANTOS; MENESES, 2009), making this domination extend to other realms, such as that of being, knowing/knowledge and nature (MIGNOLO, 2010; QUIJANO, 2014; LANDER, 2000).
} 
appearance of the phenomenon, but also its essence" (TRIVIÑOS, 2012, p. 129). In this sense, we investigate "[...] the causes of its existence, seeking to explain its origin, its relationships, its changes [...]" and attempt "[...] to infer on the consequences they will bring about to human life" (TRIVIÑOS, 2012, p. 129). The materials analyzed were mainly texts produced by the protagonists of the 1918 Reform. According to Bogdan and Biklen (1994), this material provides knowledge of historical details, such as dates, in addition to being “[...] sources of fertile descriptions of how the people who produced the materials think about their own world" (p. 176). The analysis also comprised official documents referring to student congresses held at national, regional and international levels; bibliographical material on the Reform published in the first decades after 1918; papers published in celebration of the ninety years and the centenary of this event; and current bibliography on the university internationalization theme.

The text is organized in four parts: in the first one, we present some theoretical and methodological considerations that support and contextualize the research work; the second deals with the 1918 University Reform from a historical perspective, addressing the national, regional and international context of the time; the third one talks about the Latin American projection of the 1918 University Reform as part of the history of university internationalization in the region; and the fourth part brings final considerations, where we identify, based on the analysis carried out, what the Córdoba Reform has to contribute to university internationalization in Latin America a hundred years later.

\section{THE 1918 UNIVERSITY REFORM FROM A HISTORICAL PERSPECTIVE}

The University of Córdoba (1613) was one of the first higher education institutions in Latin America, together with the University of Santo Domingo (1553), the University of San Marcos (1551), the University of Mexico (1551) and the University of San Carlos (1595), all of them created in the context of the 
Spanish colonization and supported by a religious order (LEITE, 2018). In the case of Córdoba, in the $17^{\text {th }}$ century the city housed a Catholic diocese founded by the Jesuits who created the University of Córdoba in 1613. According to Leite (2018, p. 41), starting in the century of its foundation until the beginning of the $2 \mathrm{O}^{\text {th }}$ century, the University of Córdoba "[...] followed the models of medieval European institutions and [maintained] its academic orientation and organization within the precepts of the founding religious order". This model was characterized by the use of the scholastic teaching method; the rejection of changes to the current order; the lifelong permanence of professors in their positions through university chairs; student non-participation in university government decisions; and limited access to the university, with young people from upper class families (men), dedicated to politics and/or commerce, being those admitted to these institutions.

As for knowledge, it was encapsulated and encrypted, which led to an impermeability of the university actors in the transmission of knowledge that did not dialogue with the city life and with the context in which the university was inserted (ARATA, 2018). The students at the University of Córdoba defined science very eloquently when they noted in the 1918 Opening Manifesto that: “[...] science passes silent by these mute and closed houses, or enters mutilated and grotesque for bureaucratic service" (BARROS, et al. [1918] 2017, p. 28, our translation).

In the book Facundo (1845), the Argentinian educator Sarmiento described the city of Córdoba with an emphasis on criticizing the influence of the religious order on the city and on educational institutions, considering them confined in the Middle Ages. In this sense, he points out:

This learned city has not yet had a public theater, has not known opera, has no newspapers still, and printing is an industry that could not take root there. The spirit of Córdoba until 1829 is monastic and scholastic [...] the city is a cloister enclosed between ravines; its sidewalk is a cloister with iron gates; each block has a cloister of nuns or friars; schools are cloisters; the legislation that is taught, Theology; all the 
scholastic science of the Middle Ages is a cloister in which intelligence is trapped and dammed, against everything that comes out of the text and commentary [...] (SARMIENTO, 1874, p. 76, our translation).

In that paragraph, Sarmiento refers to an anachronistic university, to a university of yesterday, which was characterized by having dark cloisters and by training doctors, in theology and law, who did not dialogue with their surroundings and other sorts of knowledge. Thus, Sarmiento's criticism was centered on the narrow mindedness of the city and of the university to other worldviews, such as modernity, which he knew how to build during his travels to the United States and to different European countries. Based on this international formation, he considered that the influence of the Church in Córdoba created a delay that impeded the progress of the province and of the country.

These considerations about the University of Córdoba and the city itself are elements that help us understand why the University Reform unfolded there. As Buchbinder (2018) argues, the role of the university in forming the elites in Córdoba society was fundamental, given that:

[...] a university degree opened a large number of doors, and to a greater extent than in other countries. But in Córdoba this was even more intense because the elite that governed there was defined essentially as a university elite and as a doctoral elite, [...] any reform of the power structure in the province of Córdoba had to be [...] a university reform. Therefore [...], the fear of the provincial ruling class of losing this control, this monopoly of power, caused this University to become more and more restrictive and more closed in the beginning of the $20^{\text {th }}$ century (BUCHBINDER, 2018, p. 32, our translation).

Given this scenario, education was a privilege of a few and served the purpose of reproducing the elite of Córdoba society. However, this was also a characteristic common to the rest of the country. According to quantitative data, until 1918 Argentina had 8 million inhabitants, of which almost 9 thousand were university students, who, in their turn, accounted for approximately $0.1 \%$ of the country's total population that year (BUCHBINDER, 2018). In the first decade of 
the $20^{\text {th }}$ century, this privilege began to be tensioned with the change in social composition as a result of various migratory flows arriving in Argentina.

Back then, an annual average of 120,000 immigrants arrived in the country and, soon in 1914, according to the population census, $30 \%$ of the population was foreign (BALARDINI, 2018). Immigrants contributed to increasing the number of factory workers, which, together with an important economic growth generated by Argentina entering the world meat market, became a factor that triggered the rise of a middle class. With immigration, the ideas developed by anarchism and socialism in Europe also arrived, which were taking root in the national context. According to Puiggrós (2018), in this process "[...] there is a society that politically becomes more complex. New social contingents aspire to ascend and have the illusion of reaching it if their children reach university" (p. 53, our translation).

In a climate of demands and social pressure, this middle class was included in the political and social life of the country after the Saenz Peña Law (1912), which established the universality3, the mandatory character and secrecy of voting suffrage. This Law allowed the Radical Civic Union [Unión Cívica Radical] (UCR) to have a place in the government; it was composed of a combination of exploited social sectors, which included the proletariat, medium sectors, sectors opposing the imperialist and oligarchic interests of the time, and sectors made up of nationalist intellectuals (PUIGGRÓS, 2016).

Among these sectors, there was a major concern about the international and regional issues of the time. Regarding the former, it is interesting to look at the political situation in Europe, since it was, and still is, a continent with influence over its old colonies. In the last decades of the $19^{\text {th }}$ century and the beginning of the $20^{\text {th }}$, Europe was surprised by great technological advances that changed the living conditions of the population, as well as by an important social unrest in several countries, a product of the underlying conflict between capital

\footnotetext{
3 It is worth noting that the word universality appears in the law, but the right to vote was only exercised by society's men.
} 
and labor (BALARDINI, 2018). This tension had an important repercussion in Argentina due to the increase in migratory flows to the Río de la Plata. At the international level, the First World War (1914-1918) should be mentioned as well, which involved the main powers of the time, generating a reconfiguration of the world power (BALARDINI, 2018), along with the Russian Revolution, which internationally showed the organization of workers and soviet soldiers, with important impacts also on education, due to their criticism of the dominant pedagogy (PUIGGRÓS, 2016).

At the regional level, the Mexican Revolution, which began in 1910, establishes itself as the triumph of the first national liberation movement on the continent (BERMANN, 1946). It was the first time in the history of Latin America that the revolution and the government that emerged from it sided with the oppressed classes in recognizing the existence of a class struggle. On the other hand, in these first years of the $20^{\text {th }}$ century, the organization of students from several Latin American countries begin, starting an incipient Latin American movement that would expand after the 1918 Reform. Some manifestations of the origin of this movement include several congresses, such as the $1^{\text {st }}$ Central American Congress of University Students, held in 1901 in Guatemala; and the International Student Congresses of 1908 in Montevideo, 1910 in Buenos Aires, and 1912 in the city of Lima.

Against the background of this national, regional and international context, between the years 1917 and 1918, the level of conflict between students at the University of Córdoba and professors and university authorities increased, leading to the process known as the 1918 University Reform. The pinnacle of this event was in June 1918, when students took over the Dean's office of the university and organized their struggle around several postulations, which were expressed in the manifesto of the University Federation of Córdoba, entitled La juventud argentina de Córdoba a los Hombres Libres de Sudamérica, published in Gaceta Universitaria, the press agency of that federation. The manifesto was written by Deodoro Roca, a law graduate from that university, and signed by 
several students of the federation.

According to Darcy Ribeiro (1975, p. 123), the demands expressed in the 1918 Reform Movement manifesto could be summarized as follows: a) Student co-government; b) Political, teaching and administrative autonomy of the university; c) Election of all of the university's representatives by assemblies representing professors, students and alumni; d) Selection of the teaching staff through public tenders that ensured wide freedom of access to the teaching profession; e) Establishment of mandates with a fixed term (five years in general) for the exercise of teaching, which can only be renewed by means of an assessment of the professor's efficiency and competence; f) Free-of-charge higher education; g) Assumption, by the university, of political responsibilities with the nation and the defense of democracy; h) Teaching freedom; i) Implementation of free chairs and the opportunity to teach courses parallel to those of chair professors, giving students the possibility of choosing between them; and j) Free class attendance. In addition to these points, the young students also incorporated the demand for secularism in education and the need to strengthen ties and collaboration within the Latin American student movement.

In 2018, the $100^{\text {th }}$ anniversary of the manifestation of these demands was celebrated. For this reason, taking advantage of the centenary of the 1918 Reform, we deem it important to revisit the history of this event in order to understand the configuration of that hora americana, or American time, as a call to solidarity for an entire continent. On this anniversary, it is also pertinent to reflect on the projection of the reform as part of the history of the university internationalization process in Latin America and its legacy for us to think about internationalization at the present time. 


\section{THE PROJECTION OF THE REFORM IN LATIN AMERICA}

As mentioned in the introduction to this article, internationalization has become a topic of global interest in recent decades. Along with this advance, one of the main characteristics of internationalization is the hegemony of the modern Western discourse (STEIN, 2017; JONES; DE WIT, 2012) in practices, policies and programs concerning higher education at an international level. Thus, an asymmetrical relationship is imposed on the global geopolitics of knowledge between a center and a periphery, where Latin America presents itself as a region that, in terms of internationalization, follows the mainstream of the Global North (ABBA, 2018). 4

In this context, it is relevant to introduce a brief reflection on the imitation of internationalization experiences produced in hegemonic knowledge centers and the lack of knowledge about or disregard for those experiences produced in the South. Earlier, In the $19^{\text {th }}$ century, Simón Rodríguez warned us about the danger of imitating foreign models, alien to the Latin American reality and, in contrast, considered that we should create original projects: "[...] America should not IMITATE slavishly, but be ORIGINAL instead" (RODRÍGUEZ, 2008, p. 48, our translation). The idea of being original was linked by Simón Rodríguez to the possibility of inventing a social project rooted in our land, without copying or transplanting experiences developed in other contexts. In this sense, when asking where we will look for reference models, he vigorously uttered a phrase that characterized his thinking: "[...] we either Invent or Fail" (RODRÍGUEZ, 2008, p. 138, our translation). Inspired by Simón Rodríguez, Enrique Rodó, who was one of the inspiring sources of the 1918 University Reform, also problematized the imitation of foreign models, considering said imitation as a form of submission to the North, a nordomanía that, by imitating those who

\footnotetext{
4 However, in recent years there has been a proliferation of Latin American studies (PERROTTA) 2016; OREGIONI, 2017; LEAL, 2020; ABBA, 2018) that are part of what Stein (2017) calls critical internationalization studies, which are characterized by the problematization of the romantic, neutral and depoliticized view of the hegemonic perspective of internationalization.
} 
deem themselves superior, presents itself as opposing those native to our Latinity (RODÓ, 1949).

The rejection of imitation was one of the characteristics of the University Reform student movement, which proposed the construction of a proper sense of university rooted in the Latin American context. To this end, the youth of Córdoba, in the Manifesto a los hombres libres de Sudamérica, asked for the collaboration of student movements from all over America and invited them to join in the revolutionary work that was beginning: "[...] we are stepping on a revolution, we are living in an American time" (BARROS, et al. [1918] 2017, p. 27, our translation). This reference to the regional aspect in the struggle of the student movement can also be found in other parts of the Manifesto, such as:

Sacrifice is our best incentive; the spiritual redemption of American youth is our only reward, as we know that our truths - and painful ones - are the whole continent's truths (p. 28).

The University Federation of Córdoba believes that the country and America must be made aware of the moral and legal circumstances that invalidate the voting act verified on June 15 (p. 29).

[...] the birth of a true revolution was and still is envisaged, one that will soon gather all free men on the continent under its flag (p. 29).

Let us resort to the lesson, comrades from all over America; if it has the sense of a glorious omen, the virtue of a call to the supreme fight for freedom; it shows us the true character of university authority, tyrannical and obsessed, which sees in every petition an aggravation, and in every thought a seed of rebellion. (p. 31).

The university youth of Córdoba, through their federation, greets its members from all over America and encourages them to collaborate in the work of freedom that is beginning (p. 31).

According to Mariátegui (2012), even though students in Latin America were motivated by particular struggles of their own university life, after the Córdoba Reformation they seemed to speak the same language around the urgent need to renovate the archaic structures of the Latin American university. The Reform thus became one of the strongest and most original expressions about 
questioning the oligarchic order shaped in our continent, since the process of political independence of Latin American countries (AROCENA, 2004). In this sense, Gregorio Bermann, one of the protagonists of the 1918 University Reform, stated in his book La Juventud de América:

Oppressed by the same anguish, touched by the same hope, young people felt united from the very first moment by an American cause and by universal purposes [...] The new generation felt the drama of a Continent subjected to the law of the masters from the inside, and of the bosses from the outside, and planted themselves in the face of that past by launching their challenge. Enough! Their purpose was to blow up a structure, a system, to start in America a new historical period (BERMANN, 1946, p. 149, our translation).

As shown in table 1, the news of the Córdoba Reform spread and the call from the students of Córdoba to Latin American youth did not take long to be answered in other countries of the continent, mainly in Peru, Uruguay, Chile, Mexico, Colombia and Cuba.

Chart 1 - Timeline of the projection of the Córdoba University Reform in the student movements of Latin America (1919-1929).

\begin{tabular}{|c|c|l|}
\hline YEAR & COUNTRY & \multicolumn{1}{c|}{ EVENT } \\
\hline 1919 & Peru & $\begin{array}{l}\text { The University Reform movement begins at the Universidad de San } \\
\text { Marcos (Lima). }\end{array}$ \\
\cline { 2 - 3 } & Uruguay & $\begin{array}{l}\text { The "Ariel" Student Center is founded. They launch a journal named } \\
\text { after the center. }\end{array}$ \\
\hline 1920 & Peru & $\begin{array}{l}\mathbf{1}^{\text {st }} \text { National Congress of Peruvian Students. The resolution of the } \\
\text { congress proposes the creation of the "González Prada" Popular } \\
\text { Universities. }\end{array}$ \\
\cline { 2 - 3 } & $\begin{array}{c}\text { Peru- } \\
\text { Argentina }\end{array}$ & $\begin{array}{l}\text { The president of the Argentinian University Federation [Federación } \\
\text { Universitaria Argentina } \text { (FUA), Gabriel del Mazo, signs an } \\
\text { agreement with the president of the Student Federation of Peru, Víctor } \\
\text { Raúl Haya de la Torre, guided by the resolutions of the international } \\
\text { congresses of Latin American students held in Montevideo, Buenos } \\
\text { Aires and Lima. }\end{array}$ \\
\cline { 2 - 3 } & Chile & $\begin{array}{l}\mathbf{1}^{\text {st }} \text { Student Convention of Chile. The first issue of the Student } \\
\text { Federation of Chile's journal is published, called "Claridad". }\end{array}$ \\
\hline
\end{tabular}




\begin{tabular}{|c|c|c|}
\hline \multirow[t]{2}{*}{1921} & Mexico & $\begin{array}{l}1^{\text {st }} \text { International Student Congress, known as the first continental } \\
\text { event of the Reform. Guests from all over the world participated, } \\
\text { especially students from Latin America. }\end{array}$ \\
\hline & Chile & $\begin{array}{l}\text { The Student Federation of Chile sends a message to the Student } \\
\text { Federation of Peru, celebrating the centenary of the Peruvian } \\
\text { independence. }\end{array}$ \\
\hline \multirow[t]{2}{*}{1922} & Colombia & $1^{\text {st }}$ National Congress of Colombian Students (Medellín). \\
\hline & Chile & form Campaign in Chile. \\
\hline 1923 & Cuba & $1^{\text {st }}$ National Congress of Cuban Students. \\
\hline \multirow[t]{3}{*}{1924} & Colombia & $2^{\text {nd }}$ National Congress of Colombian Students (Bogotá). \\
\hline & Panama & $\begin{array}{l}\text { The Panamá Society of Law Students sends a letter repudiating the } \\
\text { incorporation of its territory into the United States. }\end{array}$ \\
\hline & Cuba & Creation of the Confederation of Cuban Students. \\
\hline 1925 & France & The Latin American General Student Association is formed in France. \\
\hline \multirow[t]{2}{*}{1926} & El Salvador & The General Student Association is created in El Salvador \\
\hline & Panama & $\begin{array}{l}\text { The Student Federation of Panama plans a Bolivarian congress, } \\
\text { inviting all Hispanic American countries. }\end{array}$ \\
\hline 1927 & Paraguay & $\begin{array}{l}\text { The Student Federation of Paraguay incorporates the reformism into } \\
\text { its ideological affiliation, and declares that the movement is united } \\
\text { with the university youths of Argentina, Chile, Peru, Ecuador, } \\
\text { Colombia, Cuba and Uruguay. }\end{array}$ \\
\hline \multirow[t]{3}{*}{1928} & Bolivia & First Student Convention in Bolivia. \\
\hline & Uruguay & Law students strike in Uruguay, lasting one year \\
\hline & Brazil & $\begin{array}{l}\text { Students from Rio de Janeiro launch a Pro-University Reform } \\
\text { Manifesto }\end{array}$ \\
\hline \multirow[t]{2}{*}{1929} & Uruguay & $\begin{array}{l}\text { The Federation of Uruguayan University Students [Federación de } \\
\text { Estudiantes Universitarios del Uruguay) (FEUU] is founded. }\end{array}$ \\
\hline & Mexico & The Organic Law on University Autonomy is sanctioned. \\
\hline
\end{tabular}

Source: Prepared by the authors, based on the CLACSO collection on the Reform (2018).

With regard to Peru, the university reform movement begins at the University of San Marcos (Lima) in 1919, inspired by the Argentinian reform and led by Victor Haya de la Torre. This young student presided the Peruvian University Federation [Federación Universitaria del Perú] (FUP) and, later, became the founder of the American Popular Revolutionary Alliance [Alianza Popular Revolucionaria Americana] (APRA), which is currently operating in the form of a political party in Peru. The following year, in 1920, Peruvian students organized their First National Congress; one of the most important results of this meeting was the creation of the Gonzalez Prada Popular Universities, which aimed to promote solidarity and unity between students and the Peruvian 
proletariat. On this aspect, Mariátegui (2012), who was also one of the symbols of the Peruvian university reform, pointed out that it was thanks to the collaboration between the workers' unions and the student vanguards of Peru, united in the fight against conservative forces, that the student movement achieved a political orientation that went beyond solely-university goals. Thus, the University Reform was turning into a social phenomenon of transversal character that expanded to other sectors, which were affected by the consequences of the capitalist model of production and domination.

Another land where the Córdoba reform was projected was Uruguay, although this country had already experienced some advances in higher education before 1918 (LANDINELLI, 2008). About that, two events that unfolded in 1908 can be highlighted. The first one, related to the sanction of the Organic Law of the University of the Republic [Universidad de la República] (UDELAR), which partially guaranteed student participation (only graduated students) in the councils of each faculty; and the second one, linked to the $1^{\text {st }}$ Congress of American Students in Montevideo, organized by the Association of Uruguayan students, with support from the national government of that time. The themes discussed at the congress encompassed the relationships between public and private universities, strengthening of ties between South American universities, student representation in the deliberative bodies of universities, demand for financial aid for students, etc.

The 1918 reform helped revive the student movement in Uruguay and ignite the flame of the students' discontent and non-conformity. With an influence on the Córdoba Manifesto, in 1919 the student center was founded under the name Ariel, inspired by the work of the Uruguayan writer José Enrique Rodó, and launched a journal with the same name. In this movement, the figure of Carlos Quijano stood out; he was one of the leaders of the reform process in Uruguay and one of the founders of the journal Ariel. From 1921 onwards, interclaustral assemblies were held, in which students and professors participated, but the level of conflict increased with the strikes of university 
students for the exam system, and of high school students for the national reform of this level of education. At the end of that decade, university students decide to create the Federation of Uruguayan University Students (FEUU) and, in 1930, held the $1^{\text {st }}$ National Congress of Uruguayan Students.

Chile was another of the main countries where the call that the students of Córdoba included in the 1918 Manifesto was echoed and had an impact on the national movement. Even though Chilean students already had a federation created in 1907, it is from 1918 onwards that they advocate for a national university reform, with the same demands for autonomy, co-government and, in the Chilean case (just as the Peruvian one), overcoming the limits of the university and helping it reach society as a whole, involving other sectors such as workers. It is in this sense that the Federation of Chilean Students [Federación de Estudiantes Chilenos] (FECH) decides to create in 1918 the Lastarria Popular University for the instruction of the working class.

The year 1920 was also important for the Chilean student movement, as the $1^{\text {st }}$ National Student Convention was held and, taking advantage of this event, the first issue of the FECH's journal, entitled Claridad, was published. In the middle of that year, social conflicts in the country increased and, in parallel, the Chilean government militarized the border with Peru, on the verge of a war conflict. Because the Chilean student movement had become an obstacle for the national government, since it questioned its policies, a campaign of persecution and harassment against students started, with the allegation of betrayal of the country for their connection with the student movement in Peru. Far from ending the $\mathrm{FECH}$, these events reinforced the struggle of the movement and even strengthened ties with students from Peru. 
Figure 1 - Image of the projection of the University Reform in Latin America.

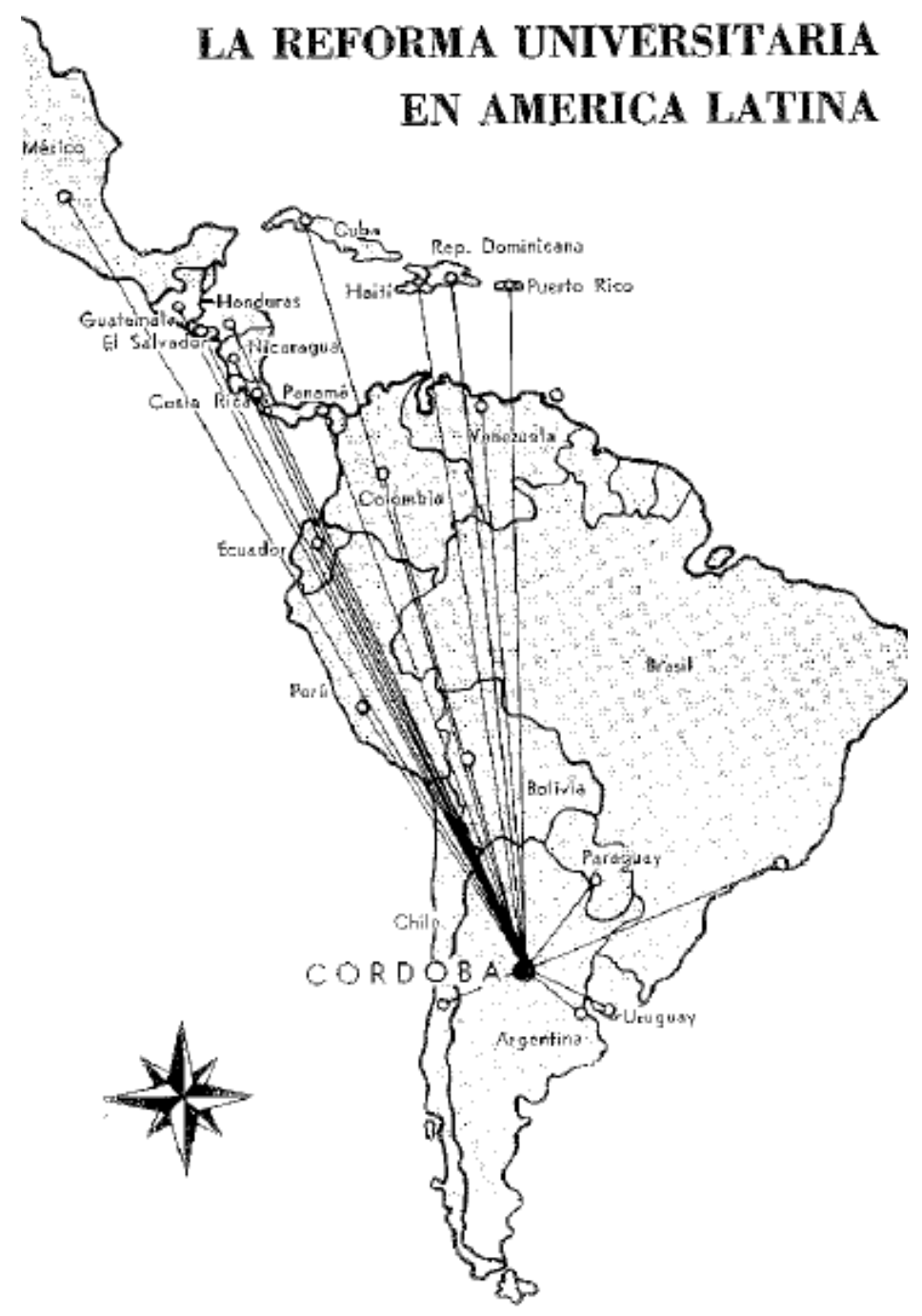

Source: COSEC, 1959.

In this way, the Córdoba Reform was projected in Latin America (Figure 1) in accordance with the context of each place, and adapted to the different national realities, imprinting its own characteristics. However, it is still necessary to ask how the situation in Brazil was at that time, and what the impact of the reform was in this country of continental dimensions.

In the $16^{\text {th }}$ and $17^{\text {th }}$ centuries, the Spanish crown had implemented several 
universities in its colonies, such as the one in Córdoba, but, in the case of Brazil, the situation was different due to the policy of the Portuguese crown and its relationship with its colonies. According to Azevedo; Braggio; Mendes Catani (2018, p. 41):

[...] while Hispanic-American universities existed for more than four centuries, because Spain had a policy of establishing universities in its colonies to meet the demand for bureaucratic and administrative positions, Luso-American universities were in an embryonic process. In Brazil, there was still no university-like institution, only faculties and schools isolated from higher education.

Later, during the First Republic (1889-1930), these institutions were located in different parts of the Brazilian territory, showing a fragmented higher education that threatened the modernization of the country. The first Brazilian university was the University of Rio de Janeiro, created in 1920, followed by the University of Minas Gerais (1927) and the University of São Paulo (1934). Thus, even though the Brazilian youth movement was the protagonist of several struggles during the colonial period (BERMANN, 1946 DEL MAZO, 1968), when the 1918 Reform took place there was no Brazilian university student organization at the national level that would answer Córdoba students' call for fight and unity.

Only at the end of the 1920 s the reform begins to have a significant impact on Brazil with the birth of the Brazilian university movement (AZEVEDO; BRAGGIO; MENDES CATANI, 2018). In 1928, students from Rio de Janeiro created a Central Committee in favor of University Reform and a body for the diffusion of this committee, called Folha Acadêmica. That same year, the students released a document, entitled Manifesto dos estudantes de Rio de Janeiro aos seus companheiros no país, in which they mentioned the 1918 Reform as a relevant antecedent: 
demands in favor of the educational mission. It seems to us the glorious movement of Córdoba, the brilliant page that the Argentinian youth wrote, inspired by the highest and most generous dreams of freedom and social justice (MENEGES, et al., 2018 [1928], p. 115, our translation).

The Córdoba event is mentioned several times in that document, and so is the youth movement in Chile and the Uruguayan writer Enrique Rodó. This shows that students from the University of Rio de Janeiro were aware of the student struggles generated in other contexts, as well as of the intellectual influences of the Latin American university movement. In this way, even though the Brazilian university movement has belatedly joined in the struggle for a higher education reform, if we take as reference the impact that this process had on other countries, one can consider that its growth was rapid and articulated. This was the case, for instance, of the Declaration of the Confederation of Brazilian Universities, released two years after the Manifesto dos estudantes de Rio de Janeiro, of 1928, which defended didactic and administrative autonomy, the responsibility of students in directing the cloister, and the necessary political and social roles of professors and students in accordance with the country's needs; another example was the creation of the National Student Union [União Nacional de Estudantes] (UNE) as a result of the celebration of the second National Student Congress in Brazil, in 1938.

For this projection of the University Reform on a regional scale, the legacy left by several Latin American intellectuals, such as Manuel Ugarte, Enrique Rodó, José Ingenieros, among others, was fundamental, as they helped in the creation of a continental idea of union in the face of the advance of the North American imperialism in the region, and in the face of the perpetuity of rigid structures in universities. Bergel (2008) stresses that this continental idea was translated into a Latinoamericanismo desde abajo, which was successfully built thanks to the transnational networks that young reformists created through travels, letter exchange, and publications in journals of continental reach.

Thus, the Reform, which had its origin in the city of Córdoba, became a 
regional flag, showing that those young students had a conscience that crossed national borders and permeated the principles that guided their revolutionary practice. The Reform created an essential connection between students, professors and intellectuals from different countries who desired to acquire knowledge of an international character. For these reasons, the process that began in 1918 and recently celebrated its centenary, set an important precedent in the university system in Latin America. In the concluding chapter, we point out elements of the 1918 Reform that, according to our analysis, can contribute to the current internationalization process.

\section{FINAL CONSIDERATIONS: CÓRDOBA'S CONTRIBUTIONS TO INTERNATIONALIZATION IN LATIN AMERICA}

The main objective of this study, as indicated in the Introduction, was to understand how the Córdoba Reform represents a historic milestone in the path of Latin American universities, in which we could also identify contributions to the current university internationalization. Both the description of the Reform itself and the details of its expansion through most countries in Latin America and the respective connections between students and professors show that this movement has many faces to be considered when we speak today of internationalization, faces which can project the effective participation of Latin America in the construction of a critical and solidary internationalism. In this concluding section, we point out some more remarkable aspects that, in their peculiarities, deserve a deeper analysis in future studies.

First of all, it is necessary to highlight the background of the international context in which the movement is inserted. In Argentina, as it has been registered, immigrants arrived and, together with their dreams of a better life, also brought political ideals they learned while struggling in their countries of origin, such as the anarchist and communist movements, both with a strong international 
tendency. Despite the clash with the traditional elites at the service of whom education was provided, the reformists were aware that there was a changing world out there and that, at the same time, it was not just a matter of transplanting a European model.

In the call for the hora americana there was the recognition that it was about thinking of the Latin American university, echoing Simón Rodríguez, based on the originality of its people and at the service of whom the university should be. Originality, in this case, did not mean a xenophobic attitude, but having a look that values that which comes from within in terms of culture and social organization. This is expressed in the tradition of José Martí, who, in Nuestra América, written in 1891, proclaimed: "The European university will surrender to the American university. [...] Let the world be grafted into our republics, but the trunk ought to be that of our republics" (MARTí, 2005, p. 34).

This stance today is manifest in the concept of critical interculturality (WALSH, 2010; TUBINO, 2004), which goes beyond the mere acceptance of the existence of the other or a functional adaptation for an open dialogue. This interculturality can contribute to the development of a critical and alternative internationalization against the hegemonic model that it is built desde abajo. This means the construction of new horizons led by the subordinates of the capitalist system, the inclusion of their values, attitudes and identities, and the establishment of relationships under conditions of equality and equity (ABBA, STRECK, 2019).

The intercultural view of internationalization constructed as of the Córdoba Reform has its most significant expression in the regional integration of the countries of South America and Central America. As we have seen, in the student movement, the senses of integration, union and fraternity were present, based on the legacy of the modernist masters who were largely responsible for sowing the ground for the projection of the Reform across the continent. Rescuing this view of regional integration of the Reform allows us to reflect on the current internationalization process, but specifically with regard to the $3^{\text {rd }}$ Regional 
Conference on Higher Education [III Conferencia Regional de Educación Superior] (CRES) for Latin America and the Caribbean, held in the city of Córdoba, to celebrate the centenary of the Córdoba Reform. The final declaration of the conference was composed of a summary of the main discussions held on different thematic axes, including Higher education, internationalization and integration of Latin America and the Caribbean. Soon at the beginning of the summary of this axis, it was stated that: "In the region, internationalization must sustain an interinstitutional cooperation based on a solidary relationship between equals, with an emphasis on the South-South cooperation and regional integration" (CONFERÊNCIA ..., 2018, p. 7).

To this end, the recommendation in the declaration was based on the promotion of intercultural dialogue, respect for the identity of other countries, the formation of inter-university networks, and the strengthening of collaboration and interaction with our academic peers from the region and the world; actions that the reformists had already rehearsed in the process of projecting the reform through travel, letter exchange, and publication in journals of regional reach.

This attempt to conceive internationalization in association with regional integration is motivated by the affirmation of the social relevance of the university and the conception "[...] of knowledge as a strategic social good, in favor of the sustainable development of the region and of the other countries" (CONFERENCE ..., 2018, p. 7). This concern with the relationship between university and society was part, since the beginning, of the 1918 University Reform through the demand of students to bring down the walls of the university and connect it with the local and regional problems that affected the population. An example of this concern was present in the expansion of the González Prada Popular Universities in Peru for rural and city workers, where an international dimension of the world of labor was fostered.

Another relevant aspect that can contribute to conceiving a less homogenizing internationalization is the demand for the autonomy of the Latin 
American university, understood as an independence from the structures of ecclesiastical and state power, but also perceived as a production of original knowledge, generated from and for Latin America. In this sense, autonomy represents the social commitment of the university to the problems that affect communities and the search for solutions in accordance with their particularities. In the current internationalization process, it is not uncommon to see the uncritical adoption of concepts on the theme, produced in other latitudes, taken as a possible commodity that can be sold and purchased, and internationalization as a means to enhance this transaction. Therefore, for an autonomous conception of the Latin American internationalization process, it would be relevant to incorporate into the analysis the concept of autonomy defended by reformist students, and to use it in the definition of what is important for the educational, historical and political project of Latin America.

Not least, a fundamental contribution of the Córdoba Reform and the reformist movements linked to it lies in the challenge of looking at the agents that take the lead in internationalization. In the literature on internationalization, as a general rule, students are the object of institutional policies, both national and international, with their participation limited to choosing between alternatives created for them. It is decided in these policies and strategies which the priority countries are, the areas that deserve the allocation of resources, and the modalities made available. Given this context, it is worth asking questions about the international academic ties that are being built by students today. Are these ties being controlled by the functional perspective towards an internationalization strongly based on market parameters, or are these relationships collaborating for the construction of a solidary and critical internationalization?

The analysis of the Córdoba Reform process as a whole and its recovery as an antecedent of university internationalization in Latin America points to the prominent role of this movement in the construction of the history of internationalization and of an autonomous and integrationist view of this 
process. The study evidences that the Córdoba Reform represented a break with the university paradigms of the past and the need for a change in educational practices and senses, generating a before and an after in the life of Latin American universities. Thus, having as inspiration the epigraph that appears in the initial considerations of the article, which brings the first words of the Córdoba manifesto, it is possible to consider that we are living once again (or still) the hora americana, or American time, which consists of the challenge of seeing internationalization as a movement of permanent search among peoples seeking to know each other and build their future together.

\section{REFERENCES}

ABBA, Maria Julieta. Límites y potencialidades para el desarrollo de una internacionalización de la educación superior necesaria: estudio de caso de la UNILA (Brasil) y la ELAM (Cuba). 2018. 279f. Tese (Doutorado em Educação) - Programa de Pós-Graduação em Educação, Universidade do Vale do Rio dos Sinos (UNISINOS), São Leopoldo, Brasil, 2018. Disponível em: http://www.repositorio.jesuita.org.br/bitstream/handle/UNISINOS/7062/Mar \%C3\%ADa\%20Julieta\%20Abba_.pdf?sequence=1\&isAllowed=y. Acesso em: 4 jul. 2018.

ABBA, Maria Julieta; STRECK, Danilo R. Interculturality and internationalization: approaches from Latin America. Simon Fraser

University Educational Review, Simon Fraser University, British Columbia, v.12, n. 3, p. 110-126, 2019. Disponível em:

https://journals.lib.sfu.ca/index.php/sfuer/article/view/1020. Acesso em: 15 jan. 2020.

ALTBACH, Philip G. The New Internationalism: Foreign Students and Scholars. Studies in Higher Education, London, United Kingdom, v. 14, n. 2, p. 125136, 1989.

ALTBACH, Philip G.; KNIGHT, Jane. Visión panorámica de la internacionalización en la educación superior: motivaciones y realidades.

Perfiles Educativos, UNAM, México DF, v. 28, n. 112, p. 13-39. 2006.

Disponível em:

http://www.scielo.org.mx/scielo.php?script=sci_arttext\&pid=So185- 
26982006000200002. Acesso em: 25 jul. 2018.

ALTBACH, Philip. G., DE WIT, Hans. The new nationalism and internationalisation of HE. University World News, London, United Kingdom, n.474, September, 2017. Disponível em:

https://www.universityworldnews.com/post.php?story=20170914073027157. Acesso em: 25 jul. 2018.

ARATA, Nicolás. Para leer el manifiesto liminar: nota. Política Universitaria, Buenos Aires, Argentina, v. 5, n. 23, p. 44-49, 2018.

AROCENA, Rodrigo. Las reformas de la educación superior y los problemas del desarrollo en América Latina. Revista Educação e Sociedade. Campinas, v. 25, n. 88, p. 915-936, 2004.

AZEVEDO, Mário Luiz Névez de; BRAGGIO, Ana Karine; MENDES CATANI, Afrânio. A Reforma Universitária de Córdoba de 1918 e sua Influência no Brasil: um foco no movimento estudantil antes do golpe de 1964. Revista

Latinoamericana de Educación Comparada, Buenos Aires, Argentina, v. 9, n. 13, p. 37-51, 2018. Disponível em:

http://www.saece.com.ar/relec/revistas/13/art4.pdf. Acesso em: 18 nov. 2019.

BALARDINI, Sergio. La Reforma Universitaria, entre um mundo em vértigo y el juvenilismo filosófico. In: PERCZYK, Jaime. A cien años de la Reforma Universitaria: conferencias en la Universidad Nacional de Hurlingham. Villa Tesei: Universidad Nacional de Hurlingham, 2018. p. 131-154.

BARROS, et al. La Juventud argentina de Córdoba a los hombres libres de Sudamérica. Manifiesto de la Federación Universitaria de Córdoba. In: TATIÁN, Diego. Córdoba, 1918: la invención y la herencia. Ciudad Autónoma de Buenos Aires: IEC-CONADU. 2017 [1918], p. 27-31.

BERGEL, Mario. Latinoamérica desde Abajo: las redes transnacionales de la Reforma Universitaria (1918-1930). In: SADER, Emir; GENTILI, Pablo; ABOITES, Hugo (Comp.). La reforma universitaria: desafíos y perspectivas noventa años después. Buenos Aires: Consejo Latinoamericano de Ciencias Sociales - CLACSO, 2008, p. 146-184. Disponível em: http://biblioteca.clacso.edu.ar/clacso/gt/20101109062939/sader.pdf. Acesso em: 25 jul. 2018.

BERMANN, Gregorio. La Juventud de América. Sentido histórico de los movimientos juveniles. México: Ediciones Cuadernos Americanos, 1946.

BOGDAN, Robert. C.; BIKLEN, Sari Knopp. Investigação qualitativa em 
educação: uma introdução à teoria e aos métodos. Portugal: Porto Editora, 1994.

BUCHBINDER, Pablo. El ciclo Reformista. In: PERCZYK, Jaime. A cien años de la Reforma Universitaria: conferencias en la Universidad Nacional de Hurlingham. Villa Tesei: Universidad Nacional de Hurlingham, 2018. p. 17-44.

CONFERÊNCIA Regional de Educação Superior (CRES) para América Latina e o Caribe. Declaração. Córdoba, Argentina 2018. Disponível em:

https://www.proifes.org.br/documentos/declaracao-cres-2018-1/. Acesso em: 4 jul. 2018.

\section{DE WIT, Hans (Ed.). Strategies for internationalization of higher}

education: a comparative study of Australian, Canada, Europe and United States. Amsterdam: European Association for International Education, 1995.

DE WIT, Hans. Internationalization in Higher Education, a Critical Review. Simon Fraser University Educational Review, Simon Fraser University, British Columbia, v.12, n. 3, p. 9-17, 2020. Disponível em: https://journals.lib.sfu.ca/index.php/sfuer/article/view/1036. Acesso em: 15 jan. 2020.

DE WIT, Hans. Internationalization of Higher Education: Nine Misconceptions. International Higher Education, Boston College, Newton, Massachusetts, n. 64, p. 6-7, summer, 2011.

DE WIT, Hans; HUNTER, Fiona; HOWARD Laura; EGRON-POLAK, Eva. (Eds.). Internationalisation of Higher Education. Brussels: European Parliament, Directorate-General for Internal Policies, 2015. Disponível em: https://www.europarl.europa.eu/RegData/etudes/STUD/2015/540370/IPOL_ STU(2015)540370_EN.pdf. Acesso em: 17 jul. 2019.

DEL MAZO, Gabriel. La Reforma Universitaria. Propagación Americana. Lima: Universidad Nacional Mayor de San Marcos, 1968. Tomo 2.

DIDOU AUPETIT, Sylvie. La internacionalización de la educación superior en América Latina: Transitar de lo exógeno a lo endógeno. México: Unión de Universidades de América Latina y el Caribe (UDUAL), 2017. Disponível em: https://www.udual.org/principal/wpcontent/uploads/2018/o6/1-INTERNACINALIZACION.pdf. Acesso em: 23 set. 2019.

GARCIA GUADILLA, Carmen. Complejidades de la globalización e internacionalización de la educación superior. Interrogantes para América 
Latina. Cuadernos del CENDES, Universidad Central de Venezuela, Caracas, v. 22, n. 58, p. 1-22, 2005.

JONES, Elspeth, DE WIT, Hans. Globalization of internationalization: Thematic and regional reflections on a traditional concept. The International Journal of Higher Education and Democracy, Baltimore, Maryland, v. 3, p. 35-54, 2012. Disponível em:

https://www.researchgate.net/publication/263611295_Globalization_of_Inter nationalization_Thematic_and_Regional_Reflections_on_a_Traditional_Conc ept. Acesso em: 30 jun. 2018.

KNIGHT, Jane. Internationalization: Elements and Checkpoints. Canadian Bureau for International Education, Otawa, Canada, n. 7, p. 1-15, 1994.

LANDER, Edgardo (Comp.). La colonialidad del saber: eurocentrismo y ciencias sociales. Perspectivas latinoamericanas. Buenos Aires: CLACSO Consejo Latinoamericano de Ciencias Sociales, 2000.

LANDINELLI, Jorge. Trazos del Movimiento Reformista Universitario en Uruguay. In: SADER, Emir; GENTILI, Pablo; ABOITES, Hugo (Comp.). La reforma universitaria: desafíos y perspectivas noventa años después Buenos Aires: Consejo Latinoamericano de Ciencias Sociales - CLACSO, 2008. p. 104111. Disponível em:

http://biblioteca.clacso.edu.ar/clacso/gt/20101109062939/sader.pdf. Acesso em: 25 jul. 2018.

LEAL, Fernanda Geremias. As bases epistemológicas dos discursos dominantes de 'internacionalização da educação superior' no Brasil. 2020. 339f. Tese (Doutorado em Administração) - Programa de Pós-Graduação em Administração, Universidade do Estado de Santa Catarina (UDESC), Florianópolis, Brasil, 2020. Disponível em:

https://www.researchgate.net/publication/339710394_As_bases_epistemologi cas_dos_discursos_dominantes_de_'internacionalizacao_da_educacao_superi or'_no_Brasil. Acesso em: 15 mar. 2020.

LEITE, Denise. A Pedagogia da Reforma de Córdoba. Revista Integración y Conocimiento, Universidad Nacional de Córdoba, Córdoba, v. 1, n. 8, p. 3753, 2018. Disponível em:

https://revistas.unc.edu.ar/index.php/integracionyconocimiento/article/view/ 20103. Acesso em: 27 abr. 2019.

MARIÁTEGUI, José Carlos. 7 ensayos de la interpretación de la realidad peruana. 76. ed. Lima: Biblioteca Amauta, 2012. 
MARTÍ, José. Nuestra América. 3. ed. República Bolivariana de Venezuela: Fundación Biblioteca Ayacucho, 2005.

MENEGES, Djacir; LOBO, José B.; DECUSATI, José; LOBO, Francisco; PEREIRA DA SILVA, Firuso. Los estudiantes de Brasil. Manifiesto de los estudiantes de Río de Janeiro a sus compañeros en el país. In: PORTANTIERO, Juan Carlos. El proceso de la Reforma Universitaria (1918-1938): crónicas, documentos, testimonios y polémicas. Ciudad Autónoma de Buenos Aires: Editorial de la Facultad de Filosofía y Letras Universidad de Buenos Aires, [1928] (2008). p. 115-118.

MIGNOLO, Warter. Desobediencia epistémica: retórica de la modernidad lógica de la colonialidad y gramática de la descolonialidad. Buenos Aires: Ediciones del Signo, 2010.

OREGIONI, María Soledad. La internacionalización universitaria desde una perspectiva situada: Tensiones y desafíos para la región latinoamericana.

Revista Internacional de Educação Superior, Unicamp, Campinas, v. 1, n. 3, p. 114-133, 2017. Disponível em:

https://periodicos.sbu.unicamp.br/ojs/index.php/riesup/article/view/8650578 . Acesso em: 30 jun. 2018.

PERROTTA, Daniela. La internacionalización de la Universidad. Debates globales, acciones regionales. Buenos Aires: IEC -CONADU. Universidad Nacional General Sarmiento, 2016.

PUIGGRÓS, Adriana. La educación popular en América Latina: orígenes, polémicas y perspectivas. Ciudad Autónoma de Buenos Aires: Colihue, 2016.

PUIGGRÓS, Adriana. Universidad y educación pública: uma historia de luchas y derechos. In: Perczyk, Jaime. A cien años de la Reforma Universitaria: conferencias en la Universidad Nacional de Hurlingham. Villa Tesei:

Universidad Nacional de Hurlingham, 2018. p. 45-67.

QUIJANO, Aníbal (Ed.). Des/colonialidad y bien vivir. Un nuevo debate en América Latina. Perú: Editorial Universitaria de la Universidad Ricardo Palma, 2014.

RIBEIRO, Darcy. A universidade necessária. 2. ed. Rio de Janeiro: Paz e Terra, 1975 .

RODÓ, José Enrique. Ariel. Buenos Aires: Editorial Sopena, 1949.

RODRÍGUEZ, Simón. Inventamos o erramos. Caracas: Monte Ávila Editores Latinoamericana, 2008. 
SARMIENTO, Domingo Faustino. Facundo o civilización y barbarie en la Pampas Argentinas. Cuarta edición en castellano. Paris: Librería Hachette y Cía, 1874.

SECRETARÍA Coordinadora de Uniones Nacionales de Estudiantes - COSEC.

La Reforma Universitaria en América Latina. Publicação da VIII Conferência Internacional de Estudantes, realizada em Lima (Peru), 1959.

SOUSA SANTOS, Boaventura de; MENESES, Maria Paula (Org.).

Epistemologias do Sul. Coimbra: Almedina/CES, 2009.

STEIN, Sharon. Internationalization for an uncertain future: Tensions, paradoxes, and possibilities. The Review of Higher Education, v. 41, n. 1, p. 3-32, 2017. Disponível em:

https://www.researchgate.net/publication/319435578_Internationalization_fo r_an_Uncertain_Future_Tensions_Paradoxes_and_Possibilities. Acesso em: 15 jan. 2020.

TEICHLER, Ulrich. Internationalisation as a Challenge for Higher Education in Europe. Tertiary Education and Management, v. 5, n. 1, p. 5-22, 1999.

TRIVIÑOS, Augusto Nibaldo Silva. Introdução à pesquisa em ciências sociais: a pesquisa qualitativa em educação. 1 ed., 21. reimpr., São Paulo: Atlas, 2012.

TUBINO, Fidel. Del interculturalismo funcional al interculturalismo crítico. In: SAMANIEGO, Mario; GARBARINI, Carmen (Ed.). Rostros y fronteras de la identidad. Temuco: Universidad Católica de Temuco, 2004. p.151-164.

TÜNERMANN BERNHEIM, Carlos. La educación superior en el umbral del siglo XXI. Venezuela: Ediciones GRESAL/UNESCO, 1996.

WALSH, Catherine. Interculturalidad, colonialidad y educación intercultural. In: VIAÑA, Jorge; TAPIA, Luis; WALSH, Catherine. Construyendo interculturalidad crítica. La Paz: Instituto Internacional de Integración del Convenio Andrés Bello, 2010. p. 75-96. 
MARIA JULIETA ABBA possui doutorado em Educação pela Universidade do Vale do Rio dos Sinos (UNISINOS). É professora e pesquisadora do Programa de Pós-Graduação em Educação da Unisinos, na linha de pesquisa Educação, Desenvolvimento e Tecnologias, membro do Grupo de Pesquisa: Mediações Pedagógicas e Cidadania e do Centro de Estudos Internacionais em Educação (CEIE). Desenvolve pesquisas vinculadas à temática da internacionalização da educação superior na América Latina, educação comparada, integração regional, interculturalidade e estudos (des)coloniais. É membro da comissão editorial da revista Educação Unisinos.

E-mail: mjulieta.abba@gmail.com

(iD) http://orcid.org/0000-0003-1248-6805

DANILO ROMEU STRECK possui doutorado em Fundamentos Filosóficos da Educação pela Rutgers - The State University of New Jersey (US). É professor da Universidade de Caxias do Sul (UCS), onde atua nos seguintes temas: educação popular, pedagogia latino-americana, mediações pedagógicas e processos participativos. É editor executivo da Revista International Journal of Action Research.

E-mail: streckdr@gmail.com

(iD) http://orcid.org/0000-0001-7410-3174

Recebido em: 22 de abril de 2020

Aprovado em: 17 de agosto de 2020

Editora responsável: Tatiane de Freitas Ermel 